\title{
Systematic Review Study: A Comparative Analysis of the State of the Art of Green Criminology
}

\author{
Ana Christina Konrad ${ }^{1}$, Luciana Turatti ${ }^{2}$, Cíntia Rosina Flores ${ }^{3} \&$ Odorico Konrad $^{2}$ \\ ${ }^{1}$ Doctoral student at the Graduate Program in Environment and Development at the University of Vale do Taquari - \\ UNIVATES. Street Avelino Talini, 171, Lajeado, Rio Grande do Sul, Brazil \\ ${ }^{2}$ Professor at the Graduate Program in Environment and Development at the University of Vale do Taquari - UNIVATES. \\ Street Avelino Talini, 171, Lajeado, Rio Grande do Sul, Brazil \\ ${ }^{3}$ Professor. University of Rondônia - UNIR. Street Presidente Dutra, 2965, Porto Velho, Rondônia, Brazil \\ Correspondence: Ana Christina Konrad - Street Avelino Talini, 171, Lajeado, Rio Grande do Sul, Brazil.
}

Received: December 13, 2019

Accepted: January 9, $2020 \quad$ Available online: January 21, 2020

doi:10.11114/ijsss.v8i2.4652

URL: https://doi.org/10.11114/ijsss.v8i2.4652

\begin{abstract}
Understanding the complex phenomena related to environmental damage requires multidisciplinary analyzes capable of producing different scientific perspectives. Based on the problems arising from issues involving environmental damage to natural resources, Flores, Konrad and Flores (2017) evaluated the studies about green criminology globally, using articles retrieved from indexed publications and available in digital databases. The present study aimed to survey the contributions that were added since the previous survey, to contribute to the understanding of what constitutes the essence of green criminology. To meet this purpose, we analyzed scientific articles published after the period investigated by Flores, Konrad and Flores (2017), which also allowed the comparison with the existing data. We employed a qualitative approach and the methodological procedure was a systematic bibliographic review. We concluded that in the last three years there has been an advance in studies about green criminology. Still, there has been a limited number of studies published in this area. Research on the theory may be limited by political and geographical issues that inhibit the plurality of spatial and local perceptions regarding the theme. Also, they restrict preventive actions to environmental damage due to lack of knowledge and research, as the theory acts directly on preventive measures and protection of nature.
\end{abstract}

Keywords: green criminology, systematic review, environmental damage, environmental protection, ecological justice, digital collections

\section{Introduction}

The global environmental conjuncture increasingly demonstrates the yearnings for environmental protection. This scenario is reflected in international agreements, treaties and conventions that preach rules among the signatory countries, aiming at environmental conservation in the process of sustainable development. Therefore, it is necessary to have a harmonious integration between socio-spatial aspects and natural characteristics, thus revealing an environmental justice (Ioris, 2009; Jacobi \& Giatti, 2015; Pellizzaro, L., Hardt, C. Hardt, M. Hardt \& Sehli, 2015).

In contrast, the society-nature interaction favors environmental damage, since humans do not respect territorial or even natural limits, which leads to short, medium- and long-term harmful effects, impacting the environment directly and indirectly. Degradation occurs several times, in an irreparable and irreversible manner, leaving harmful consequences for both humanity and nature. This reflects the permeability of contemporary boundaries, connected by transnational dimensions, at political, social and economic levels (Bisschop, 2015; Castro, Hogenboom \& Baud, 2011).

The so-called border events come from a risky society that is founded on exacerbated consumption, rampant waste, low investment in renewable energy, disregard for environmental education and lack of ethical commitments to recognize the need to limit the exploitation of natural resources (Leite \& Silva, 2012; Beck, 2011). In order to efficiently fight environmental damages, it is mandatory to understand the various factors and actors involved. Then, preventive actions and procedures can be put in place, as well as public policies based on environmental governance (Hinojosa, 2012; Zhouri, 2008; Nobles, 2019). 
Given this scenario, it is understood that the issues regarding environmental degradation require multidisciplinary analyzes capable of giving different scientific perspectives to understand the complex phenomena related to environmental damages. Criminology emerges in the environmental sciences, assuming that environmental damage is an area of criminological research. It leads to the contemporary phenomenon called "green criminology", a concept that has been increasingly used in reference to environmental crimes, damages, laws and justice (Fitzgerald \& Baralt, 2010; Hinojosa, 2012; Milaré, 2013; Sanchez, 2013; South, Brisman \& Mcclanahan, 2014; Lynch, 2017; Nobles, 2019).

Given the growing knowledge on the issues involving environmental damage to natural resources, Flores, Konrad \& Flores (2017) conducted a bibliographic and qualitative analysis involving worldwide studies about green criminology. This survey was based on indexed publications available in digital collections. The authors inventoried the scientific outputs subsidized from the scientific typology of studies related to the "theme, document authorship, institutional affiliation of researchers, spatial identification of the occurrence of discussions about green criminology in the global scenario, and chronological delimitation of publications" (Flores; Konrad \& Flores, 2017 p. 270), using as a milestone the year 1990, when the theory received the mentioned nomenclature.

The aim of this research was to evaluate the state of the art of green criminology based on the analysis of studies published after the period investigated by Flores, Konrad \& Flores (2017), and to compare the findings. The approach was qualitative, and the methodological procedure adopted was a bibliographic systematic review (Sampaio \& Mancini, 2007).

\section{Green Criminology: The Phenomenological Understanding}

Green Criminology, introduced with this nomenclature more than two decades ago by Lynch (1990), is a growing area of criminology expertise that focus on environmental damage and its scope, distribution, control and consequences (for human beings, nonhuman species and the ecosystem). Originally, green criminology was established from the understanding of how economic and political relationships promote green crime and environmental damage by affecting legal definitions, social control, the production, distribution and threats of toxic waste (Mcclanahan, \& Brisman, 2015; Barrett; Lynch \& Stretesky, 2016).

The literature on green criminology has expanded to include theoretical, qualitative and quantitative studies dealing with the causes, consequences and control of damage and green crime. These studies have focused on food crime; genetic food modification; agricultural chemicals; crimes against animals; illegal trade and transnational environmental crimes; issues related to environmental justice; environmental crime; law and social control; and even specific issues like global warming (Barrett; Lynch \& Stretesky, 2016; Goyes \& South, 2017).

The green criminology expanded the scope of criminology, drawing attention to acts of "green violence" that have commonly been ignored in the traditional criminological literature. For inspiration, ecology-based criminology draws on observations of the scientific literature outside the conventional criminology, and uses empirical basis to identify damage. Thus, green criminologists exploit environmental damages that are explicitly defined as illegal by criminal laws, as well as damage that is technically legal but certainly harmful. Green criminology is multidisciplinary and covers the environmental and political sciences, epidemiology, medical literature, geography, sociology, among others. In view of this, green criminology has been described as a perspective rather than a theory, so there is no unified "theory" of this concept (Lynch \& Stretesky, 2014; Barrett; Lynch \& Stretesky, 2016; Goyes \& South, 2017).

The term green criminology is not easily categorized (Lynch \& Stretesky, 2014) as it brings together several subjects, as well as broad theoretical and ideological conceptions. Thus, green criminology is a generic expression given to the branch of criminology concerned with the general neglect of ecological issues, within the criminal science. It proposes the incorporation of green perspectives into conventional criminology. The authors point out that they are "disturbed by the fact that, as a discipline, criminology is unable to grasp the wisdom of taking green damage more seriously" (Lynch \& Stretesky, 2014 p. 2).

This criminological typology reveals some peculiarities regarding its denomination, as there is no unanimity regarding its nomenclature (South, 2014). Mostly, the term "green criminology" is used to refer to the study of crime, injustice and environmental damage. The term has a plural conceptual understanding as natural, artificial, cultural and work-related. Moreover, the author mentions that in the international scenario there are other terminologies used to address the concept, such as: Conservation Criminology; Eco-crime; Eco-global Criminology; Environmental Criminology, as depicted in figure 1 . 


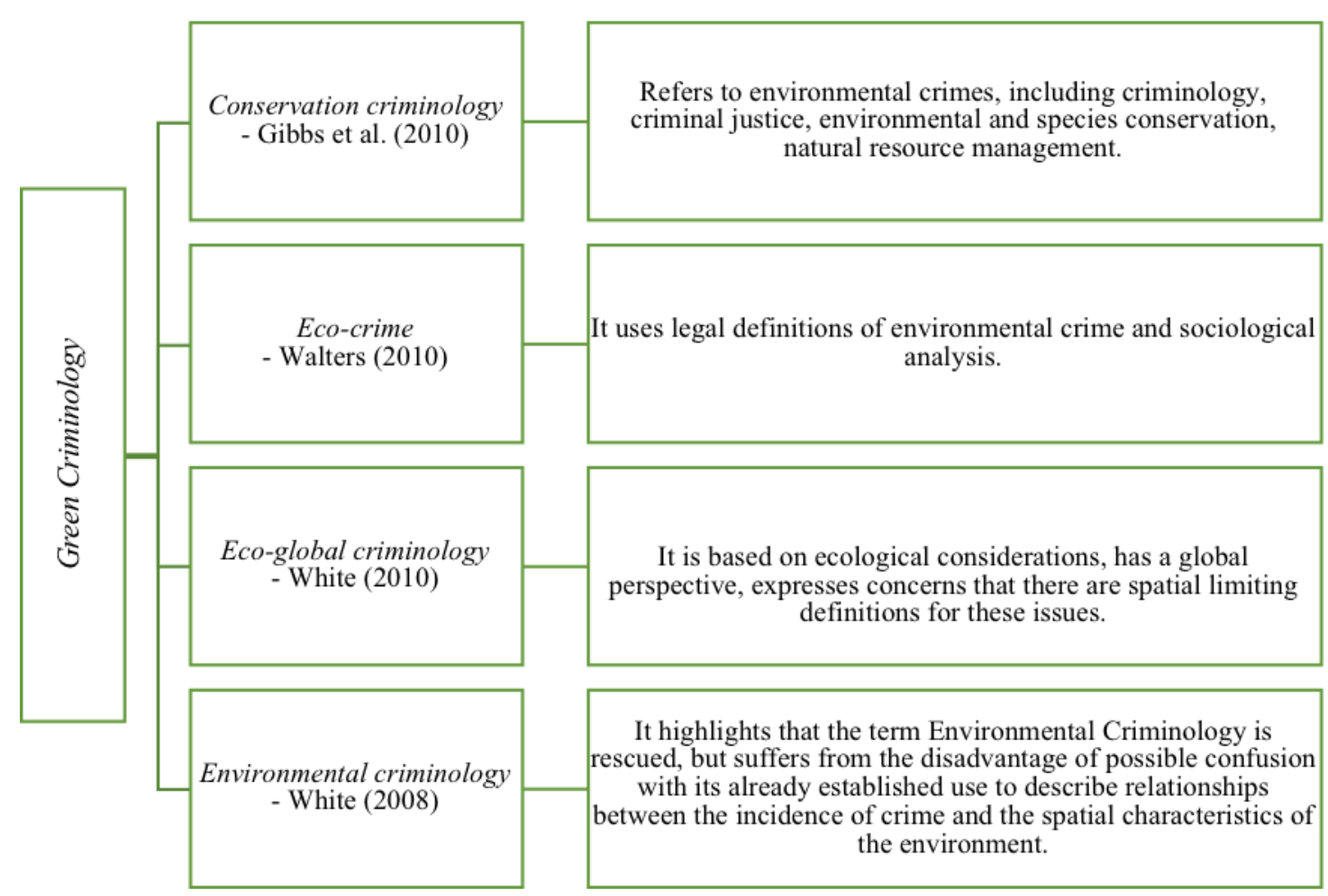

Figure 1. Terminologies used in the international scenario to refer to Green Criminology

Source: Adapted from South (2014) and Flores, Konrad \& Flores (2017 p. 271).

Green criminology, the main term used internationally, takes on interdisciplinary and multidisciplinary approaches to analyze broader environmental crimes and harms, which are often overlooked by the ruling criminology (Nurse, 2017). It therefore redefines criminology, in the sense that it no longer relates only to the crimes or social harm falling within the scope of criminal justice systems. It applies a "green" perspective to environmental crime and ecological justice, and includes the study of environmental laws and criminality, which take into account damage that affects the environment and non-human nature (Nurse, 2016; Nurse, 2017).

The green criminology analyzes the behaviors harmful to nature, theoretically and empirically, distinguishing between the actions of primary impact (i. e., that cause direct effects to the degradation of natural resources), and the secondary ones (in the mediation level; the consequences of environmental damage, such as illegal food, medicine and drinking water markets). Also, environmental issues under the bias of green criminology are classified according to damage typology (South; Brisman \& Mcclanahan, 2014; South \& White, 2014). This typology consists of a color representation - called by the authors as "Coloring Environmental Issues" - represented by brown, green and white (Figure 2). Brown depicts the means of pollution, green refers to environmental concerns, and white presents the impacts of technologies (South \& White, 2014 p. 17, 18). 


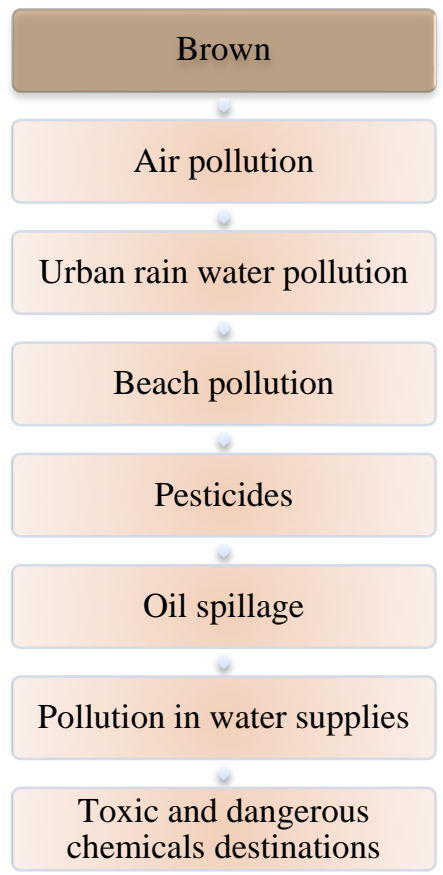

Toxic and dangerous
chemicals destinations
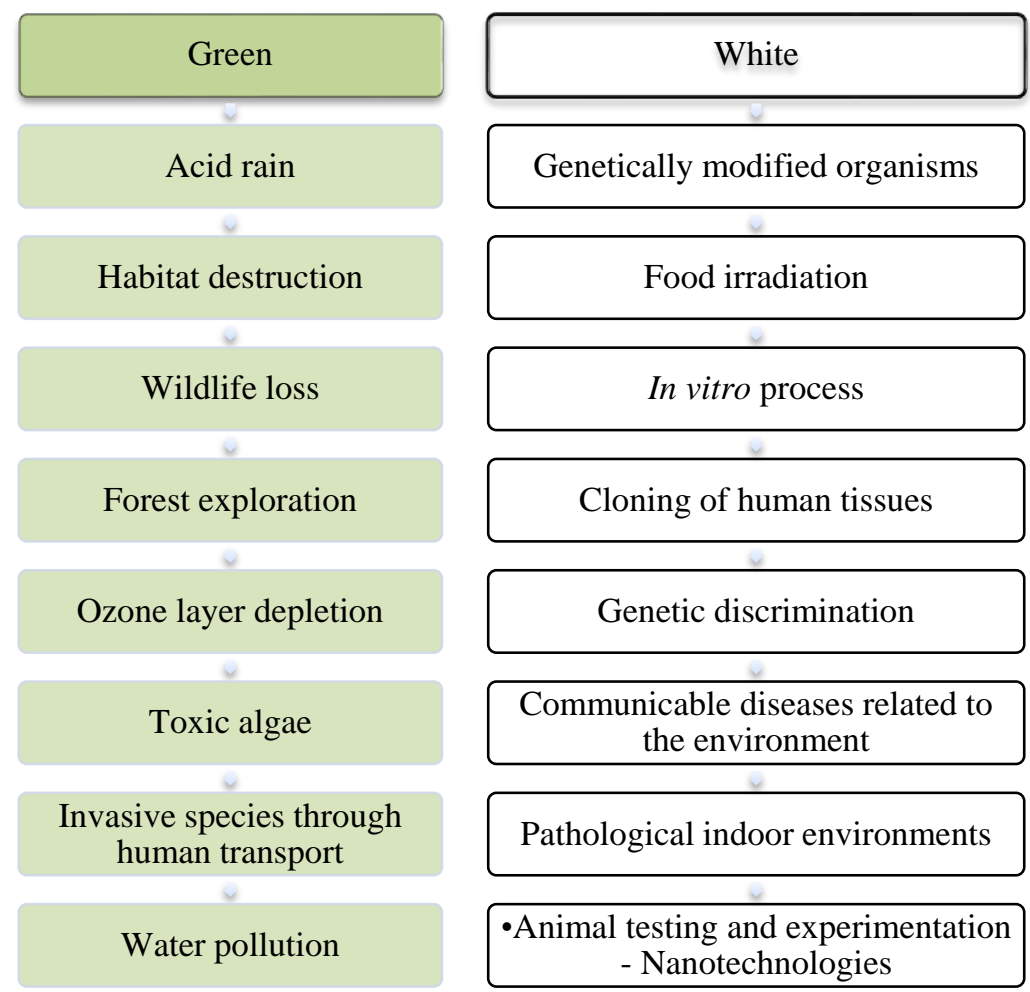

Cloning of human tissues

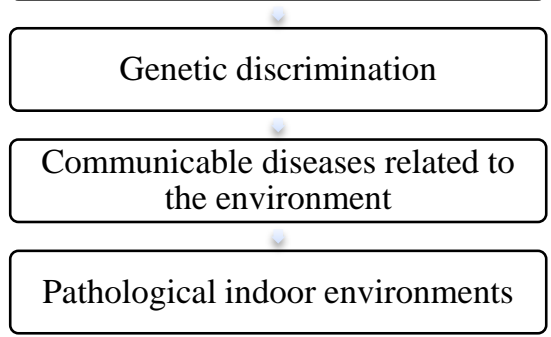

$\bullet$ Animal testing and experimentation - Nanotechnologies

Figure 2. Classification of environmental issues according to damage typology: "Coloring Environmental Issues" Source: Adapted from South \& White (2014) and Flores, Konrad \& Flores (2017 p. 272).

In the scenario of the specificities and classification of environmental damage, the objective is to make a thorough understanding of crime, in order to achieve environmental preservation. The analysis of green crimes enables the proper law enforcement, provides integrated and grounded management of criminological environmental issues, and encourages a precautionary approach to the protection of natural resources (South \& White, 2014; Nurse, 2016; Nurse, 2017).

Green crime is a fast moving, somewhat contested area, where academics, policy makers and practitioners often disagree on how green crimes should be defined, the criminal nature involved, potential solutions to green crime problems, and the content and priorities of the policy that should be adopted (Nurse, 2016).

Within the ecological justice discourse, for example, there may be consensus that harm to animals and the environment should be addressed. However, whether green crimes are best addressed through criminal justice systems or through civil or administrative mechanisms is still debatable (Nurse, 2016). There is a central discussion within green criminology as to whether green crimes should be viewed as the focus of dominant criminal justice and treated by central criminal justice bodies such as the police, or whether they should be considered outside the mainstream (Nurse, 2017).

For traditional criminology, restrictive notions of police, policing by state and crime institutions are seen only by the predominance that criminal law determines (Lynch, Long, Barrett, \& Stretesky, 2013; Lynch \& Stretesky, 2014). However, even though environmental damage is a major threat to human survival, green crime is often overlooked by the main justice systems. Consequently, ecological criminology extends beyond the focus on street and interpersonal crime to encompass the consideration of the "destructive effects of human activities on local and global ecosystems" (Lynch \& Stretesky, 2014 p. 1).

Ecology-based criminology considers not only the issues of crime defined by a strict idea of criminal law, but also examines issues relating to rights, justice, morals, victimization, criminality and the use of administrative resources, civil and regulatory justice systems. Green criminology also investigates the actions of non-state criminal justice actors such as Non-Governmental Organizations (NGOs) and civil society organizations, and the role of the state as a major contributor to environmental damage (Lynch \& Stretesky, 2014; Nurse, 2017).

State crime is a concern of green criminology, particularly regarding the responsibility to protect the environment 
and natural resources and the resultant damage when states fail to fulfill these obligations. For example, environmental resources such as water and fisheries are trusted to the public and therefore there is a broad responsibility of using these resources in the public interest. Water pollution provides an example of green victimization and how green crimes occur routinely in societies. For instance, several studies examined how states and corporations have turned water sources into commodities something that can be owned or leased and subsequently exploited (Lynch, Long, Barrett, \& Stretesky, 2013; Lynch \& Stretesky, 2014; Johnson; South \& Walters, 2016; Lynch; Stretesky \& Long, 2017; Nurse, 2017). Based on this idea, Johnson, South \& Walters (2016) identified how the privatization of water in some jurisdictions allowed corrupt companies and states to exploit a fundamental human right. At a basic level, examining the extent and control of water pollution by statutory state treatment facilities demonstrates how state failures in the use of water resources can constitute a state crime. The example above illustrates well the concern of various green criminologists regarding how neoliberal markets, capitalist systems, and the activities of other corporate legal actors can cause significant environmental damage, thus sometimes constituting environmental crimes (Ozymy \& Jarrell, 2017). A proof of this is the low level of prosecution for polluting activities, which reveal the diffuse structure of the US environmental regulatory regime and the lack of government databases, which makes the empirical assessment of environmental crimes and law enforcement efforts particularly difficult. (Ozymy \& Jarrell, 2017).

From this perspective, Lynch (2017) argues that treating pollution broadly, from the concept of "within the law" is a matter of conjecture. To find out what can be considered correct, you should look at emission data, identify pollution patterns, make scientific references and collect evidence of local emissions. This issue is a longstanding concern for radical political economists.

Ecological Marxists detail the contradiction between capitalism and ecology and note that the solution to this contradiction is a transition beyond capitalism, since its vision is based on continuous expansion, i. e., growth upon environmental destruction. Countless critics who defend the continuous growth and free-market capitalism argue that technology is the alternative solution. But it must be acknowledged that technology still needs to make its claims. This is evident, considering the increasing ecosystem destruction measures since the 1970s, and considering that carbon dioxide emissions have increased by over $80 \%$ since then (Lynch, 2017).

From the capitalist point of view, technology promotes economic growth, thereby undermining the intent of technology designed to restrain environmental damage by increasing the impact over time as production continues to expand. At the micro level, the damage to any individual production may decrease, while at the macro level, ecological damage continues to expand as capitalism grows. While technological solutions sound attractive (because they lead to growth) as individuals can stop worrying about consumption and impacts on the ecosystem, they cannot address specific dimensions of the environment (Lynch, 2017).

The problems stated above governed by the known rules of science, and no matter how hard they try, humans cannot reverse those rules. The solution is to consume less and establish a new view on the society-nature relationship that accepts zero growth as beneficial to a socioenvironmental proposal. Besides this solution, limitations to growth and consumption could be proposed (Lynch, 2017).

There is a fact that needs to be recognized, that the rich produce far more environmental damage through overconsumption. Thus, governmental limitations on consumption and income, and the progressive taxation seen in some nations, could be a way of controlling harmful effects on nature. Many solutions have been proposed in a broad literature. However, the point is, the proponents of capitalism scold these claims, undermine them and ensure that growth continues unaffected. Therefore, even though solutions exist, the economically and politically "powerful" do not want to see them implemented (Lynch, 2017).

Another concern of green criminology is wildlife crime, especially, wildlife trafficking and illegal wildlife trade, including those threatened with extinction, according to Nurse (2015) and Essen et al. (2016). The illegal killing of wild animals, particularly in agricultural and livestock areas, has recently caught the eye of green criminology scholars. The killing of large predators such as wolves and lynx has been characterized as a form of resistance, illustrating the conflict between conservation and animal protection ideologies versus the needs of traditional communities. While most states have laws to protect wildlife from human predation, hunting often remains a legal and regulated activity, and in many situations, it is approved by the community and thus constitutes a kind of organized crime. What will determine how states implement sanctions and show concern about species justice is the way the state deals with this issue (Nurse, 2015; Essen et al., 2016).

Green criminology also analyzes mechanisms to stop and prevent environmental crimes and reduce damage to animals and the environment. In cases of environmental damage, traditional models of patrolling, seizure and punishment are likely to be inadequate because irreparable environmental impacts or loss of animal life may already 
have occurred. Similarly, traditional justice systems are also often inappropriate to mitigate the damage to nature (Hall, 2017). In this sense, Hall (2017) advocates the use of approaches based on restorative justice and mediation, as the author believes that these provide alternative mechanisms for human and non-human victims of environmental crimes. These alternatives form an integral part of green criminology's critical approach to preventive enforcement, which is to prevent damage.

As highlighted by Nurse (2017), green criminology stands as a discipline that considers criminal issues not only as defined by a strictly legalistic conception of criminal law, but also considers issues related to rights, justice, morals, victimization, criminality and the use of criminal law, administrative, civil and regulatory justice systems. Therefore, it is understood that the constitution of an alternative criminology, as proposed by South (2010) and focused on the mitigation of environmental damage and injustice, requires a new academic perspective, as well as a new global policy (Nurse, 2016; Nurse, 2017; Hall, 2017; Nobles, 2019).

\section{Methods}

Data collection was performed through an exploratory survey performed in the digital library of the Portal of Periodicals of CAPES-Brazil (CAPES, 2019), a database that allows the access to various knowledge areas, including environmental, multidisciplinary, and applied social sciences. The search was carried out using the proxy of the Universidade do Vale do Taquari - UNIVATES. This method consists on verifying the diffusion of scientific knowledge and the flow of information under multiple approaches (Dias, Schultz, Schuster, Talamini, \& Révillion, 2015; Nassi-Calò, 2015).

The bibliographic survey was carried out from January 2018 to June 2019. To allow a comparison with the survey of Flores, Konrad \& Flores (2017), the time frame started from the moment the authors finalized their search, January 1st, 2016, and ended in June 1st, 2019.

In the data analysis, the research used the same system employed by Flores, Konrad \& Flores (2017 p. 274), to allow for comparisons with their results. The following variables were used in the analyzes:

a) databases - verification of the incidence of publications per database;

b) typology - establishment of document occurrence by format, based on the typology adopted by the CAPES Portal;

c) authorship - identification and classification of the most productive authors;

d) institutional affiliation - identification of the institution to which the author is affiliated academically or scientifically;

e) spatial distribution - evaluation of the spatial distribution of the discussions about green criminology in the global scenario;

f) publication chronology - survey of the temporal dynamics of the occurrences of publications, starting from the year 2016, when Flores, Konrad \& Flores finished their research (Flores, Konrad \& Flores, 2017 p. 274).

Regarding the procedure of search and selection of publications, the study used the advanced search by subject using the string "green criminology". This search was restricted to the title and subject of publications. The work proceeded with the reading of abstracts, keywords and the complete content of the publication, when necessary, to construct the theoretical framework exposed in this article, thus constituting a systematic bibliographic analysis of publications (Sampaio \& Mancini, 2007; Wemrell, 2019). In this context, the systematic review uses as a data source the publications related to a certain theme (Wemrell, 2019), thus providing a summary "of the evidence related to a specific intervention strategy, through the application of explicit and systematic search methods, critical thinking and synthesis of selected information" (Sampaio \& Mancini, 2007 p. 84).

\section{Results and Discussion}

The main results of the bibliographic survey and systematic analysis of the publications available in virtual collections and belonging to the green criminology theme are presented below.

\subsection{Sample Publications by Database and Chronology}

According to Graph 1, the string "green criminology" appears in 18 databases included in the collection of CAPES Portal, over the course of 3 years (2016-2019). Two databases - Springer Science and SAGE Publications - were the source of more than $20 \%$ of the total number of documents studies (30 documents), providing half of them (15 documents). Each remaining database contributes with less than $10 \%$ of the sample: UTP University of Toronto Press 3.1\%; Scopus (Elsevier B.V) 3.1\%; ARC Excellence in Research Australia 3.1\%; DOAJ 6.3\%; EBSCO 3.1\%; Google Scholar 3.1\%; Paperity 3.1\%; Pro Quest 3.1\%; Thunder; Ulrichs Web 3.1\%; Web of Science 3.1\%; Wiley Online 
Library 3.1\%; Taylor \& Francis Online 3.1\%; Oxford Academic 3.1\%; Science Direct 3.1\%; JSTOR 3.1\%.

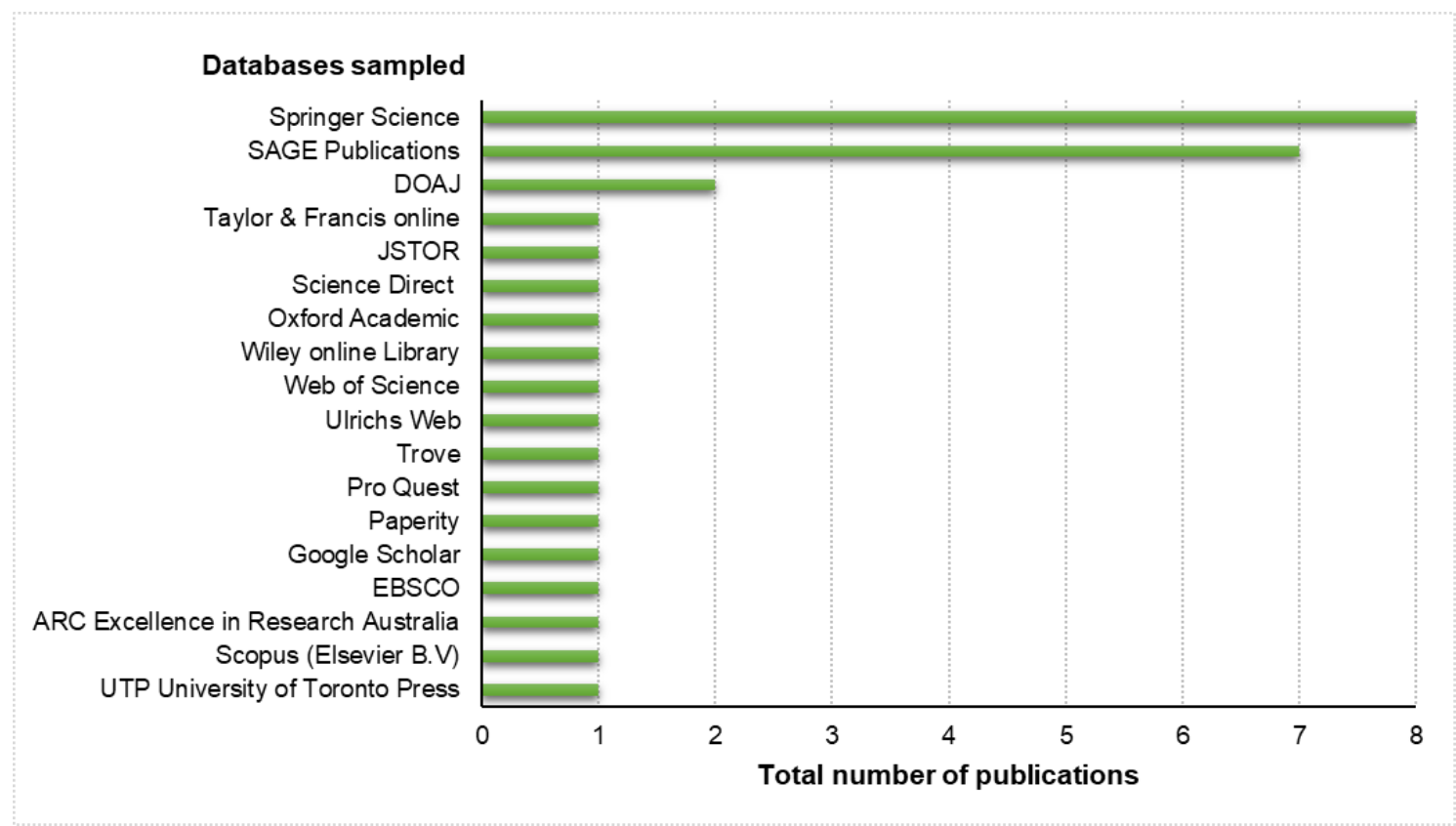

Graph 1. Number of publications per database

Source: Authors.

According to the data presented by Flores, Konrad \& Flores (2017), showed in Table 1, the string "green criminology" was found in 13 databases from the CAPES Portal. However, their study covered 26 years (1990 until early 2016) and retrieved 69 documents.

Table 1. Publications by sample of Flores, Konrad and Flores (2017) study database

\begin{tabular}{cccccccccccccccc}
\hline Database & $\mathbf{1 9 9 8}$ & $\mathbf{2 0 0 1}$ & $\mathbf{2 0 0 3}$ & $\mathbf{2 0 0 4}$ & $\mathbf{2 0 0 7}$ & $\mathbf{2 0 0 8}$ & $\mathbf{2 0 0 9}$ & $\mathbf{2 0 1 0}$ & $\mathbf{2 0 1 1}$ & $\mathbf{2 0 1 2}$ & $\mathbf{2 0 1 3}$ & $\mathbf{2 0 1 4}$ & $\mathbf{2 0 1 5}$ & Total \\
\hline Scopus (Elsevier B.V) & 0 & 1 & 1 & 1 & 1 & 0 & 0 & 1 & 1 & 2 & 16 & 9 & 8 & $\mathbf{4 1}$ \\
Web of Science & 0 & 0 & 1 & 1 & 0 & 1 & 3 & 1 & 1 & 1 & 7 & 5 & 6 & $\mathbf{2 7}$ \\
Cengage Learning, Inc. & 0 & 0 & 0 & 0 & 0 & 1 & 1 & 1 & 0 & 0 & 3 & 7 & 3 & $\mathbf{1 6}$ \\
ProQuest LLC All rights reserved & 1 & 0 & 1 & 1 & 0 & 1 & 2 & 0 & 1 & 1 & 3 & 1 & 1 & $\mathbf{1 3}$ \\
Springer Science \& Business Media & 0 & 0 & 0 & 0 & 0 & 0 & 0 & 1 & 1 & 0 & 3 & 3 & 2 & $\mathbf{1 0}$ \\
SAGE Publications & 0 & 0 & 0 & 0 & 0 & 0 & 1 & 0 & 0 & 1 & 2 & 0 & 5 & $\mathbf{9}$ \\
Oxford University Press & 0 & 0 & 0 & 1 & 0 & 1 & 0 & 0 & 0 & 0 & 1 & 1 & 1 & $\mathbf{5}$ \\
Gale Virtual Reference Library & 0 & 0 & 0 & 0 & 1 & 0 & 0 & 0 & 0 & 0 & 0 & 2 & 0 & $\mathbf{3}$ \\
Networked Digital Library & 0 & 0 & 0 & 0 & 0 & 1 & 0 & 0 & 0 & 0 & 1 & 0 & 0 & $\mathbf{2}$ \\
Inderscience Journals & 0 & 0 & 0 & 0 & 0 & 0 & 0 & 1 & 0 & 0 & 0 & 0 & 0 & $\mathbf{1}$ \\
MEDLINE/PubMed & 0 & 0 & 0 & 0 & 0 & 0 & 0 & 0 & 0 & 0 & 0 & 0 & 1 & $\mathbf{1}$ \\
Project MUSE & 0 & 0 & 0 & 0 & 0 & 0 & 0 & 0 & 0 & 0 & 0 & 0 & 1 & $\mathbf{1}$ \\
Sciencedirect & 0 & 0 & 0 & 0 & 0 & 0 & 0 & 0 & 0 & 0 & 0 & 0 & 1 & $\mathbf{1}$ \\
\hline Total & $\mathbf{1}$ & $\mathbf{1}$ & $\mathbf{3}$ & $\mathbf{4}$ & $\mathbf{2}$ & $\mathbf{5}$ & $\mathbf{7}$ & $\mathbf{5}$ & $\mathbf{4}$ & $\mathbf{5}$ & $\mathbf{3 6}$ & $\mathbf{2 8}$ & $\mathbf{2 9}$ & $\mathbf{1 3 0}$ \\
\hline
\end{tabular}

Source: Adapted from Flores, Konrad \& Flores (2017 p. 274).

By comparing the data, it was observed an increase of five databases, which demonstrates a greater diffusion of studies. It is also understood that the publications were made available on multiple international databases, which was also 
evidenced by Flores, Konrad \& Flores (2017). With the increasing diffusion of publications, there is also "a greater accessibility for researchers, students and professionals in the field". However, given that most digital collections are paid services, the number of users is still limited (Flores, Konrad \& Flores, 2017, p. 274). Therefore, in this regard, it is still concluded that the dissemination of the green criminology theory depends on the availability in a larger number of virtual collections (Flores, Konrad \& Flores, 2017). Although a large amount of available collections has been found, many of them are still linked to payment systems, which may hinder the access by researchers of different nationalities.

Regarding chronology, 30 publications referring to "green criminology" were found published in the time period established for this study (January 2016 to June 2019). In comparison, Flores, Konrad \& Flores (2017) found 69 publications over a 26 -year period. This result shows a great increase in publications related to the theme over the last years.

The "temporal dynamics of the occurrence of publications remained stagnant until 2007, experiencing gaps in 1999, 2000, 2002, 2005 and 2006" (Flores, Konrad \& Flores, 2017, p. 278). The authors also pointed out that since 2008 the theme has been evolving, although it has not been linear since "it increased, especially in 2009 and 2013, the latter representing the most productive period in terms of number of publications "(Flores, Konrad \& Flores, 2017, p. 278).

Despite that rise, the number of publications declined in 2010, 2011 and 2012, "however, the progressive growth of publication number and associated references indicates the development of communications in the field of green criminology over the past eight years" (Flores, Konrad \& Flores, 2017, p. 278), as shown in graph 2.

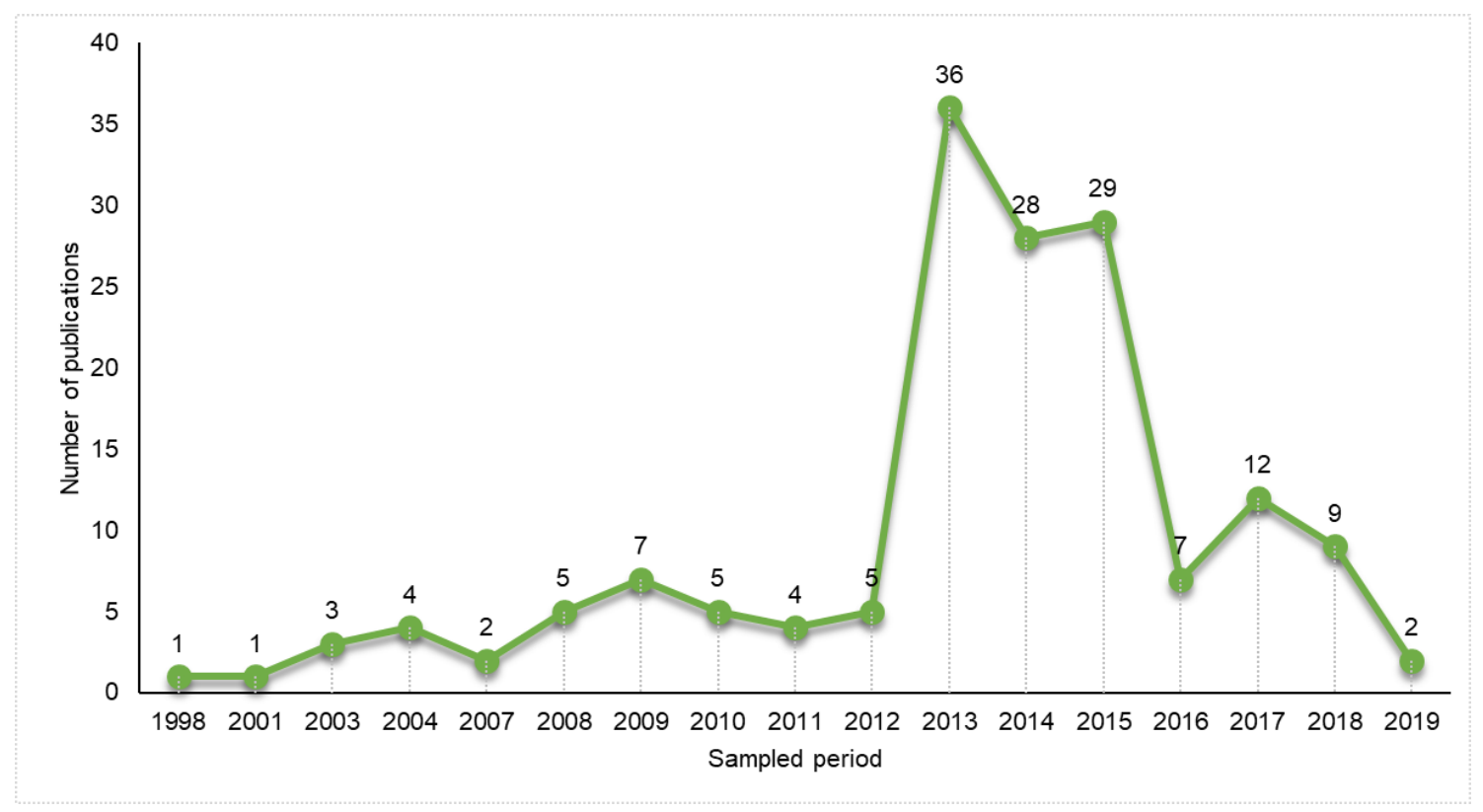

Graph 2. Annual chronology of publications according to Flores, Konrad \& Flores (2017) and chronology of publications presented in this research

Source: Authors and Flores, Konrad \& Flores (2017 p. 278).

On the other hand, as of 2016 the number of publications increased again, with the publication of 30 studies (graph 2), with peaks in 2017 and 2018 that accounted for 21 publications in total.

It should be noted that the theme had a greater visibility in international discussions from 2016 to 2019, paving the way for a sequence of publications related to green criminology. It was also observed that the subject expanded within the area of green criminology. Among the dissemination of new terminologies and concepts presented in the publications, some terms drew attention at the level of speculation, such as: green militarization; ecofeminism; critical environmental criminology; green cultural criminology; green violence; feminist criminology.

\subsection{Scientific Publications by Authorship and Typology}

Regarding authorship, its identification made it possible to verify the frequency of publications with individual authorship or co-authorship, and the researchers who stood out. Thus, our research sample had 28 authors, of which 18 had a single publication, four had two publications, and five had more than two. 
Although the results of our research identified 28 authors, $32.14 \%$ of the documents analyzed were authored by the same group of researchers (Graph 3). These data demonstrate that there was no homogeneous distribution of publications per author. This finding is similar to those presented by Flores, Konrad \& Flores (2017 p. 276), since in their research 44 authors were found but $30 \%$ of the publications belonged to a dingle group of researchers.

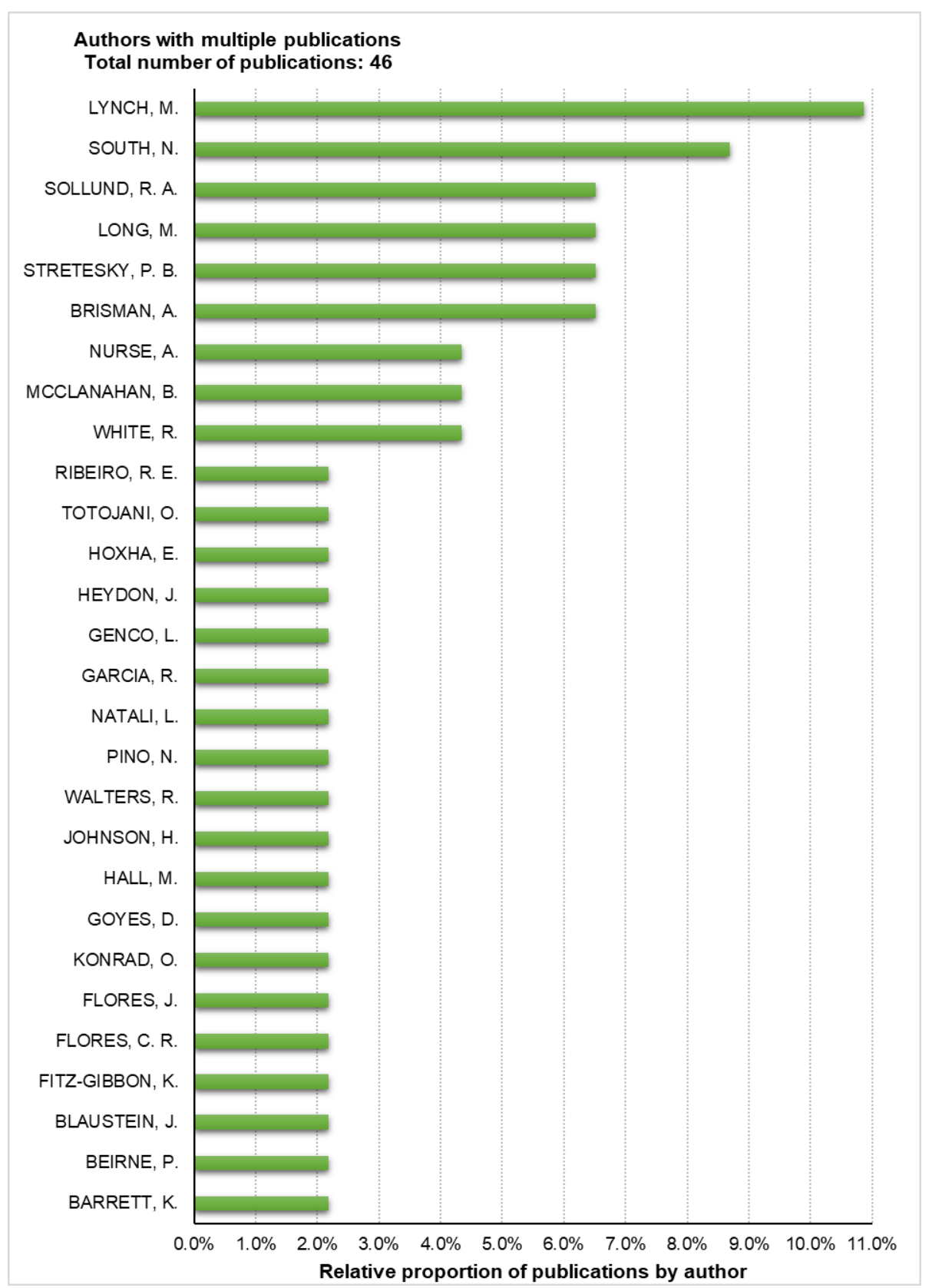

Graph 3. Authors with multiple publications: quantity and percentage in relation to the sample

Source: Authors.

Authors who have the highest percentage of publications also publish in co-authorship, which enriches their studies with the diversity of ideas brought by the plurality of authors. According to Flores, Konrad \& Flores (2017, p. 276) studies with multiple authors indicate a tendency to establish links with other researchers, aiming at developing studies in the areas of practice, "allowing the sharing of information as well as the improvement of the study through different perceptions of the object of analysis".

The results about the variable typology are presented in Graph 4. Four types of publications were found, classified according to the CAPES Portal: article, book, book chapter and dissertation (Graph 4). This differs from the typologies 
found by Flores, Konrad \& Flores (2017), who found eight types: article, book review, book chapter, book, reference entry, thesis, textual feature and report (Graph 5).

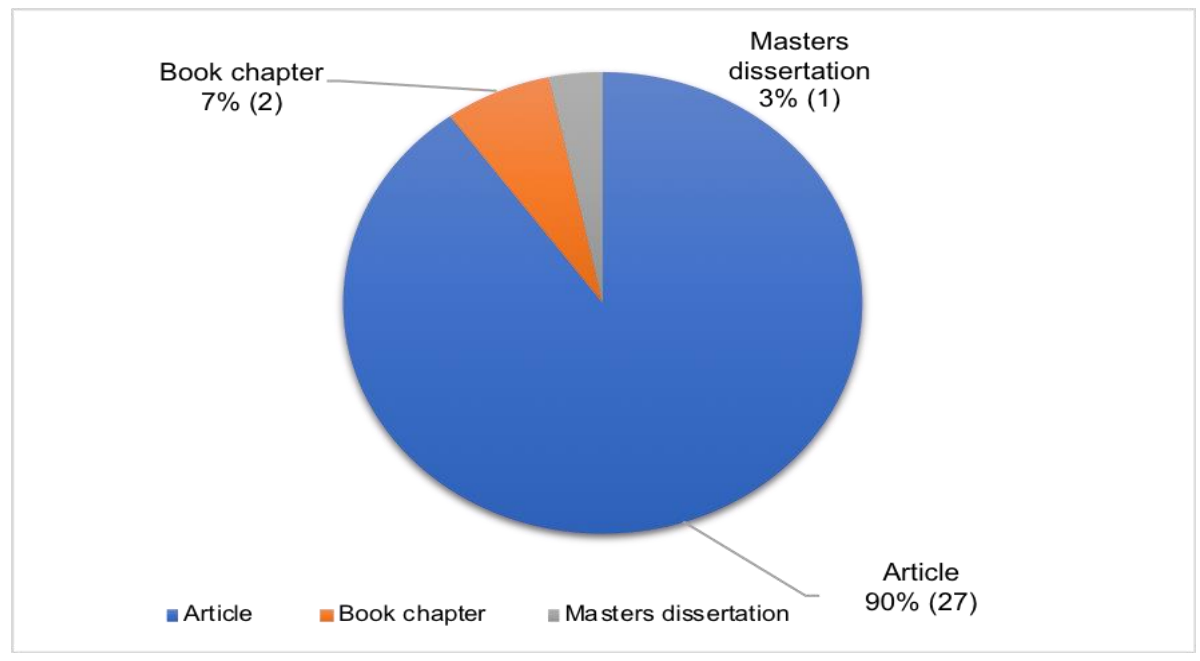

Graph 4. Scientific publications by type

Source: Authors.

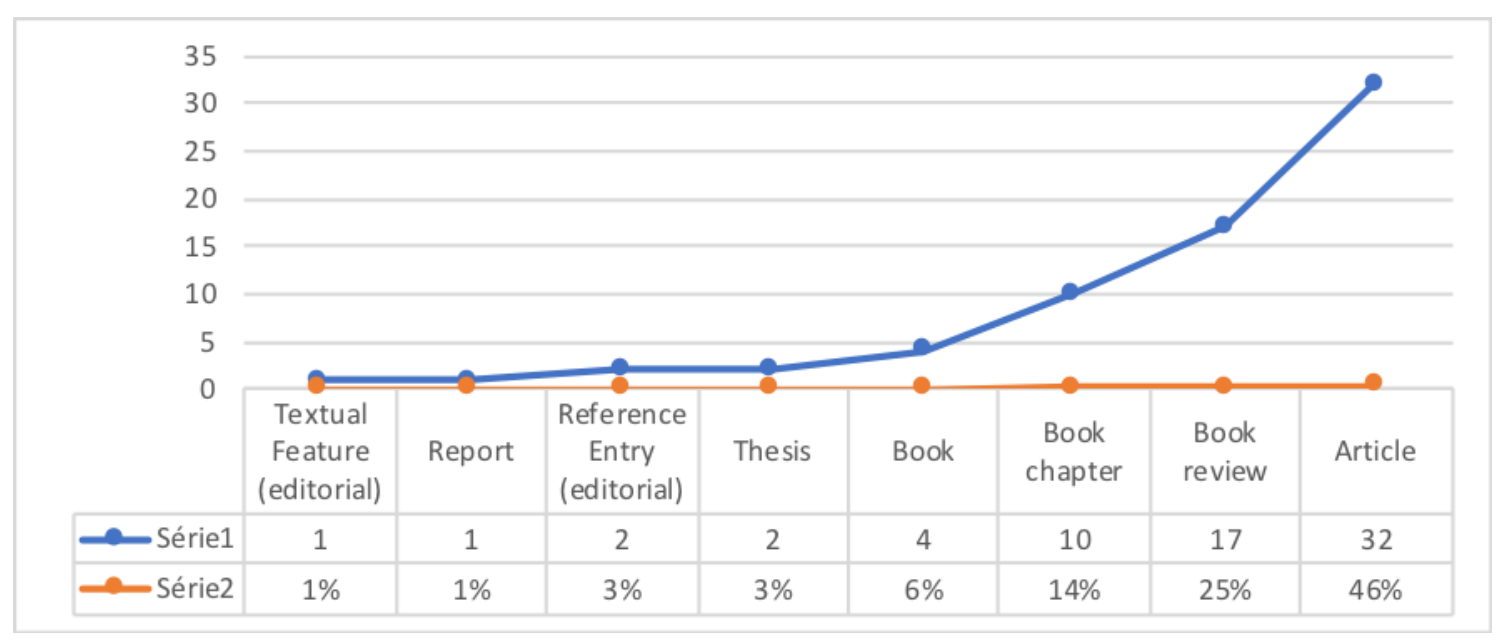

Graph 5. Number of scientific publications by type according to Flores, Konrad \& Flores (2017)

Source: Flores, Konrad \& Flores (2017 p. 275).

In both surveys, the highest percentage of scientific publications related to green criminology were articles, representing $90 \%$ of this sample and $46 \%$ of the documents presented by Flores, Konrad \& Flores. Still,

Assuming that indexing is the central pillar that guides the degree of credibility of scientific research, it is predicted that the articles under analysis went through strict acceptance criteria (peer review), giving quality, reliability and originality to the study (Flores, Konrad \& Flores, 2017, p. 275).

In addition, it was observed that another evaluative criterion of journal fixation was the impact factor, present in most citations of scientific articles, and something that indicates the representativeness of publications in their areas. According to Flores, Konrad \& Flores (2017, p. 275) the theory of green criminology, although emergent, "is published in journals with a high degree of scientific reliability and direct adherence in the area of criminology", which denotes the use of "ethical principles, significantly impacting the investigation of the theme". 


\subsection{Institutional Affiliation and Spatial Distribution}

Of the 28 authors, 25 are affiliated to universities, two to institutes and one to an education center. These data are similar to those portrayed by Flores, Konrad \& Flores (2017). Another similarity refers to the fact that none of those authors has direct or indirect ties to the public administration. This fact was noted by Flores, Konrad \& Flores (2017) as something that concerns the implementation and adoption of public policies, in order to reflect on the prevention of environmental damage.

In terms of spatial distribution, the studies were authored by researchers from seven countries. The highest concentration was in the United States, making up 48\% of the total (Graph 6), followed by Australia and Brazil (15\%), England and Austria (7\%), and Norway and Spain (4\%).

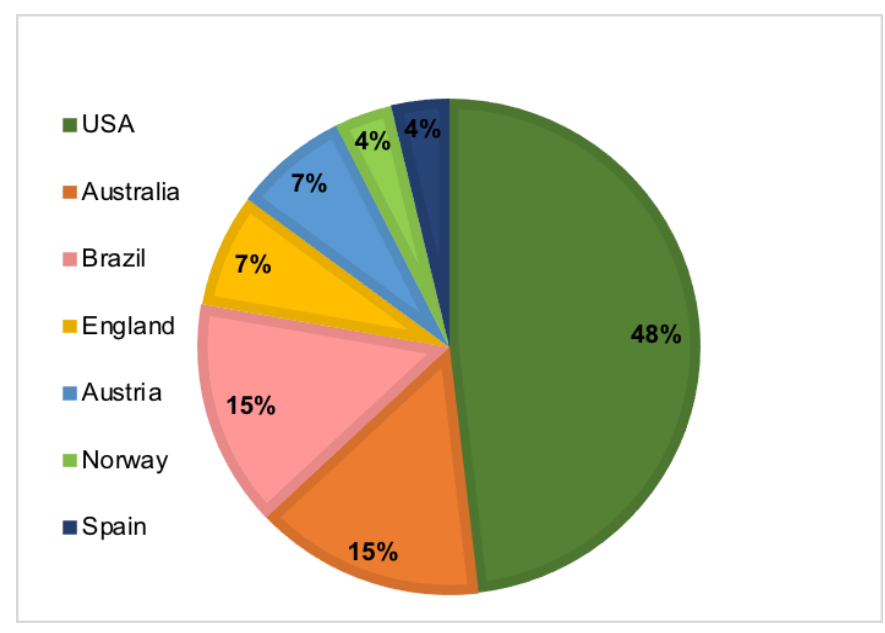

Graph 6. Occurrence of publications by countries

Source: Authors.

Similar to the survey by Flores, Konrad \& Flores (2017), the United States is the country with most research in the area. However, the data came as a surprise when comparing them with the sample of the authors, since studies appeared in three new countries: Austria, Spain and Brazil. This result draws attention to the fact that a country classified as semi-peripheral is launching studies on the theory, which was not mentioned in the previous survey (Arrighi, 1998; Ouriques \& Viera, 2017). However, researchers with multiple scientific productions are concentrated in developed countries, specifically, in the United States, Australia, England, and Austria. The absence of discussions of emerging theory denotes a connection with possible political and geographical issues (Flores, Konrad \& Flores, 2017).

There is solid evidence that research cooperation between institutions, regions or countries increases the visibility, quality and impact of the resulting publications. Bibliometric indicators of scientific production constitute a widely used methodology, especially by European researchers. In the author's words this phenomenon has been attracting the attention of decision makers as a way to foster excellence in research in various parts of the world (Nassi-Calò, 2015).

\section{Conclusions}

The information obtained through this research provided an overview of the profile of publications related to green criminology. From the systematic review and comparative study, it was possible to conclude that the literature on the subject has become wider in the last three years. Proportionally the number of publications increased significantly in this period, taking into account that the interval studied by Flores, Konrad \& Flores (2017) comprised 26 years. Only two documents were not in English, the others were published in full in English and made available in multiple databases, allowing a greater accessibility.

The sample by type revealed that the "scientific article" modality has the largest number of documents, published in journals indexed in various databases, which denotes a high degree of scientific reliability, positively impacting the investigation of the theme. In terms of authorship, the number of authors increased in terms of plurality, when compared to the previous study. However, the documents remain concentrated around a certain number of authors, which was also identified by Flores, Konrad and Flores. The co-authorship was very present, characterizing a profile of multiplicity of 
perceptions of the theory under analysis. This characteristic was perpetuated during the investigated periods, as it was already observed by the authors Flores, Konrad \& Flores (2017).

As for the spatial distribution, unlike previous research in the Americas, countries considered peripheral or semi-peripheral (Brazil) appeared in our inventory. The core nations continue to lead the percentage of research in green criminology, the focus of scientific productions on the subject.

It is concluded that in the last three years there has been an advance in studies about green criminology, however, there are still few studies published in this area. It can be understood that research related to the subject may be limited by political and geographical issues, thus inhibiting the plurality of spatial and local perceptions regarding the concept. These limitations restrict the prevention of environmental damage due to lack of knowledge and research, since the theory acts directly on the precaution and protection of nature. They also harm the semi peripheral countries, because they idealize a greater economic development. Consequently, they need to exploit their natural resources and, without research to do this properly, commit environmental crimes or extrapolate ecological limits. In this sense, green criminology stands as a proactive tool for reflection and decision-making, regarding crimes, damages, laws and environmental justice.

\section{Acknowledgment}

This study was carried out with the support of CAPES, Brazil - Financing Code 001. We wish to thank the institutions that supported us, especially UNIVATES and PROSUC/CAPES, for granting research grants and the scholarship, respectively.

\section{References}

Arrighi, G. (1998). A ilusão do desenvolvimento. Editora Vozes.

Barrett, K., Lynch, M., \& Stretesky, P. B. (2016). Green Criminology and the Reconceptualization of School Violence: Comparing Green School Violence and Traditional Forms of School Violence for School Children. Critical Criminology, 24, 19-37. https://doi.org/10.1007/s10612-015-9280-9

Beck, U. (2011). Sociedade de risco: rumo a uma outra modernidade. Tradução de Sebastião Nascimento. Rio de Janeiro: Editora, 34.

Bisschop, L. (2015). Governance of the Illegal Trade in E-Waste and Tropical Timber: Case Studies on Transnational Environmental Crime. Green Criminology Series. Farnham (UK) \& Burlington, VT (USA): Ashgate. https://doi.org/10.4324/9781315585499

Brisman, A., South, N., \& White, R. (2015). Environmental crime and social conflict. Surrey: Ashgate. https://doi.org/10.4324/9781315580012

Castro, F., Hogenboom, B., \& Baud, M. (2011). Governança ambiental na América Latina: para uma agenda de pesquisa mais integrada. Ambiente \& Sociedade, São Paulo, 14(2), 1-13. https://doi.org/10.1590/S1414-753X2011000200002

Dias, V. V., Schultz, G., Schuster, M. S., Talamini, E., \& Révillion, J. P. (2015). O mercado de alimentos orgânicos: um panorama quantitativo e qualitativo das publicações internacionais. Revista Ambiente e Sociedade, São Paulo, XVII(1), 161-182. Retrieved from http://www.scielo.br/pdf/asoc/v18n1/pt_1414-753X-asoc-18-01-00155.pdf

Essen, E., Hansen, H. P., Nordström, H., Källström, M., Peterson, N., \& Peterson, T. R. (2016). Illegal hunting between social and criminal justice. In: DONNERMEYER, J. (org.) Routledge International Handbook of Rural Criminology, Routledge, London and New York, p 319-329. https://doi.org/10.4324/9781315755885-36

Fitzgerald, A., \& Baralt, L. B. (2010). Media constructions of responsibility for the production and mitigation of environmental harms: the case of mercury-contaminated fish. Canadian Journal of Criminology and Criminal Justice, 52(4), 341-368. https://doi.org/10.3138/cjccj.52.4.341

Flores, C. R., Konrad, O., \& Flores, J. A. (2017). Green criminology: cenário das produções científica. Ibero-American Journal of Environmental Sciences, [S.1.], Aracajú, 8(4), aug. https://doi.org/10.6008/SPC2179-6858.2017.004.0022

Goyes, D. R., \& South, N. (2017). Green Criminology Before 'Green Criminology': Amnesia and Absences. Critical Criminology, 25(2), 165-181. Junho. https://doi.org/10.1007/s10612-017-9357-8

Hall, M. (2017). Exploring the cultural dimensions of environmental victimization. Nature. Article number: 17076. https://doi.org/10.1057/palcomms.2017.76

Hinojosa, T. D. G. (2012). La explicación científica en criminologia. Derecho Penal y Criminología. Revista del Instituto de Ciencias Penales y Criminológicas, 33(94), 127-153. 
Ioris, A. A. R. O. (2009). que é justiça ambiental. Ambiente \& Sociedade, 12(2), 389-392, 2009. https://doi.org/10.1590/S1414-753X2009000200012

Jacobi, P. R., \& Giatti, L. L. (2015). A ambivalência do desenvolvimento e a busca de novas vias para a sustentabilidade. Ambiente \& Sociedade, 18(3), 0-0. https://doi.org/10.1590/1809-4422ASOCeditorialV1832015

Johnson, H., South, N., \& Walters, R. (2016). The commodification and exploitation of fresh water: Property, human rights and green criminology. International Journal of Law Crime Justice, 44, 146-162. https://doi.org/10.1016/j.ijlcj.2015.07.003

Leite, J. R. M., \& Silva, J. A. L. (2012). Juridicidade do dano ambiental: gestão da zona costeira e aspectos da exploração do pré-sal pelo Brasil. Sequência, Florianópolis, 65, 305-328. https://doi.org/10.5007/2177-7055.2012v33n65p305

Lynch, M. J. (1990/2006). The Greening of Criminology: A perspective for the 1990s. Reprinted in N. South \& P. Beirne (Eds.), Green Criminology. Hampshire: Aldershot.

Lynch, M. J. (2017). Conceptualizing Green Victimization, Green Criminology and Political Economy: A Reply. Critical Sociology, 43(3) 473-478. https://doi.org/10.1177/0896920516689072

Lynch, M. J., \& Stretesky, P. B. (2014). Exploring green criminology: Toward a green criminological revolution. Ashgate, Farnham.

Lynch, M. J., Long, M. A., Barrett, K. L., \& Stretesky, P. B. (2013). Is it a Crime to Produce Ecological Disorganization? Why Green Criminology and Political Economy Matter in the Analysis of Global Ecological Harms. The British Journal of Criminology, 53(6), 997-1016. https://doi.org/10.1093/bjc/azt051

Lynch, M. J., Stretesky, P. B., \& Long, M. A. (2017). State and green crimes related to water pollution and ecological disorganization: water pollution from publicly owned treatment works (POTW) facilities across US states. Nature. Article number: 17070. https://doi.org/10.1057/palcomms.2017.70

Mcclanahan, B., \& Brisman, A. (2015). Climate change and peacemaking criminology: Ecophilosophy, peace and security in the "war on climate change". Critical Criminology,23(4). https://doi.org/10.1007/s10612-015-9291-6

Milaré, É. (2013). Direito do ambiente. 8 ed. São Paulo: Revista dos Tribunais.

Nassi-Calò, L. (2015). Indicadores bibliométricos da produção científica europeia. SciELO em Perspectiva. 05 Nov. Retrieved from http://blog.scielo.org/blog/2015/11/05/indicadores-bibliometricos-da-producao-cientifica-europeia/

NOBLES, M. R. (2019). Environmental Crime and Contemporary Criminology: Making a Difference. American Journal of Criminal Justice, 44, 656-669. https://doi.org/10.1007/s12103-019-09483-7

Nurse, A. (2015). Policing wildlife: Perspectives on the enforcement of wildlife legislation. Palgrave Macmillan, London. https://doi.org/10.1057/9781137400017

Nurse, A. (2016). An introduction to green criminology and environmental justice. Sage, London. https://doi.org/10.4135/9781473971899

Nurse, A. (2017). Green criminology: shining a critical lens on environmental harm. Nature. Article number: 10. https://doi.org/10.1057/s41599-017-0007-2

Ouriques, H. R., \& Vieira, P. A. (2017). A condição semiperiférica do Brasil na econômica-mundo capitalista: novas evidências. Revista Carta Internacional, 12(3), 199-228. https://doi.org/10.21530/ci.v12n3.2017.711

Ozymy, J., \& Jarrell, M. (2017). Red state, blue state, green state: nalysing the geography of federal environmental crime prosecutions within and across the U.S. Nature. Article number: 17063. https://doi.org/10.1057/palcomms.2017.63

Pellizzaro, P. C., Hardt, L. P. A., Hardt, C., Hardt, M., \& Sehli, D. A. (2015). Gestão e manejo de áreas naturais protegidas: contexto internacional. Ambiente \& Sociedade, 18(1), 19-36. https://doi.org/10.1590/1809-4422ASOC509V1812015en

Portal Periódicos Capes. (2019). Acervo. Portal CAPES. Retrieved from http://www.periodicos.capes.gov.br/index.php?option=com_pcollection\&Itemid=104

Sampaio, R. F., \& Mancini, M. C. (2007). Estudos de Revisão Sistêmica: um guia para síntese criteriosa da evidência científica. Revista Brasileira de Fisioterapia. São Carlos, 11(1), 83-89, jan./feb. https://doi.org/10.1590/S1413-35552007000100013

Sánchez, L. E. (2013). Avaliação de impacto ambiental: conceitos e métodos. 2 ed. São Paulo: Oficina de textos.

South, N. (2010). The ecocidal tendencies of Late Modernity: Transnational crime, social exclusions, victims and 
rights. In: WHITE, Rob. (org.) Global environmental harm: Criminological perspective. Willan, Devon, p. 228-247.

South, N. (2014). Green criminology: Reflections, corrections, horizons. International Journal for Crime, Justice and Social Democracy, 3(2), 5-20. https://doi.org/10.5204/ijcjsd.v3i2.172

South, N., Brisman, A., \& Mcclanahan, B. (2014). Green Criminology. Oxford Bibliographies in Criminology. https://doi.org/10.1093/obo/9780195396607-0161

South, N., \& White, R. (2014). The antecedents and emergence of a 'Green' criminology. In: Selected Papers from the Presidential Panels: 2013 ASC Annual Meeting (Atlanta): Expanding the Core: Neglected Crimes, Groups, Causes and Policy Approaches. Retrieved from http://repository.essex.ac.uk/11798/1/South\%2C\%20Nigel-White\%2C\%20Rob.pdf

Wemrell, M., Stjernlöf, S., Aenishänslin, J., Lila, M., Gracia, E., Ivert, A. K. (2019). Towards understanding the Nordic paradox: A review of qualitative interview studies on intimate partner violence against women (IPVAW) in Sweden. Sociology Compass, 13(6), 1-23. https://doi.org/10.1111/soc4.12699

Zhouri, A. (2008). Justiça ambiental, diversidade cultural e accountability: desafios para a governança ambiental. Revista Brasileira de Ciências Sociais, 23(68), 97-107. https://doi.org/10.1590/S0102-69092008000300007

\section{Copyrights}

Copyright for this article is retained by the author(s), with first publication rights granted to the journal.

This is an open-access article distributed under the terms and conditions of the Creative Commons Attribution license which permits unrestricted use, distribution, and reproduction in any medium, provided the original work is properly cited. 